\title{
Soil metal concentrations after five years of pasture-to- sugarcane conversion
}

\author{
Camila Bolfarini Bento ${ }^{1}$ (D), Janaina Braga do Carmo ${ }^{1,2, *}$ (D), Gabriele Verônica de Mello Gabriel1,3 (D), \\ Wander Gustavo Botero ${ }^{4}$ (D), Andrea Pires Fernandes ${ }^{4}$ (D), Luiz Antonio Martinelli5 ${ }^{5}$, Luciana Camargo \\ de Oliveira ${ }^{1,3}$ (ID \\ 1. Universidade Federal de São Carlos Rợ - Programa de Pós-Graduação em Biotecnologia e Monitoramento Ambiental - Sorocaba (SP), Brazil. \\ 2. Universidade Federal de São Carlos Rợ - Departamento de Ciências Ambientais - Sorocaba (SP), Brazil. \\ 3. Universidade Federal de São Carlos Rợ - Departamento de Física, Química e Matemática - Sorocaba (SP), Brazil. \\ 4. Universidade Federal do Alagoas Rợ - Instituto de Química e Biotecnologia - Maceió (AL), Brazil. \\ 5. Universidade de São Paulo Rợ - Escola de Agricultura "Luiz de Queiroz" - Centro de Energia Nuclear na Agricultura - Piracicaba (SP), Brazil.
}

Received: Feb. 10, 2021 | Accepted: Nov. 3, 2021

Section Editor: Osvaldo Guedes Filho

*Corresponding author: jbcarmo2008@gmail.com

How to cite: Bento, C. B., Carmo, J. B., Gabriel, G. V. M., Botero, W. G., Fernandes, A. P., Martinelli, L. A. and Oliveira, L. C. (2022). Soil metal concentrations after five years of pasture-to-sugarcane conversion. Bragantia, 81, e0822. https://doi.org/10.1590/1678-4499.20210038

\begin{abstract}
Extensive pastures are commonly converted to sugarcane areas in Brazil. In soils cultivated with sugarcane, tillage and fertilization are management practices commonly carried out. Soil management practices alter the physical and chemical properties increasing or decreasing metal availability. The purpose of this study was to quantify soil metal concentrations during pasture-to-sugarcane conversion correlating these changes with physical and chemical properties. The results showed that the concentration of metals in soil samples occurred according to the following order $\mathrm{Fe}>\mathrm{Mn}>\mathrm{Cr}>\mathrm{Zn}>\mathrm{Cu}>\mathrm{Pb}>\mathrm{Cd}$. Significant increases in soil metal concentrations due the sugarcane cultivation were observed to $\mathrm{Cd}$ and $\mathrm{Cu}$. The soil physical and chemical properties presented correlations with soil metal concentrations. There was a strong relationship on inorganic fertilization to change in soil metal concentrations. The principal component analysis (PCA) explained $55.4 \%$ of the total data variance, separating factors in two groups that pointed to an influence of fertilization on metal grouping. Inorganic fertilizer application may input $1.06 \mathrm{~g} \cdot \mathrm{ha}^{-1} \cdot \mathrm{year}^{-1} \mathrm{Cd}$. The $\mathrm{Cd}$ concentration ranged from 0.15 to $1.07 \mathrm{mg} \cdot \mathrm{kg}^{-1}$, representing addictions of $9.54 \mathrm{mg} \cdot \mathrm{ha}^{-1}$.year-1 $\mathrm{Cd}$ in soil. The metal concentrations observed after five years of pasture-to-sugarcane conversion did not represent environmental risks since the concentrations remained below the Brazilian official determinations.
\end{abstract}

Key words: heavy metals, cadmium, latosol, inorganic fertilization, simple superphosphate.

\section{INTRODUCTION}

Soil contamination with metals is a serious issue that occurs in both naturals, urban and agricultural environments (Huang et al. 2020). In agricultural soil, the adsorption, complexation, precipitation and bioavailability of metals in soil are influenced by several parameters. Between them, the source materials, geochemical forms, organic matter, crop residues, $\mathrm{pH}$, bulk density, type and amount of clay, the presence of iron and aluminum oxides, cation exchange capacity and the organic matter content are examples of soil physical and chemical factors that determine the transport and fate of these trace elements (Miśkowiec and Olech 2020; Nogueira et al. 2013; Omwoma et al. 2010; Toor and Haggard 2009). It is known that some potentially toxic metals are essential micronutrients and also constituent of molecules, which perform essential functions in plants, being the toxic effect depending of the concentration and phytoavailability (Appenroth 2010).

Soil contamination depends preliminarily on the metal reaching the soil and accumulating in hazardous concentrations. In agricultural areas, there are several anthropogenic metal sources including mining, smelting, waste disposal, urban effluent, fuel residues, vehicle exhausts, sewage sludge, pesticides, liming and organic and inorganic fertilizer application (Alloway 
1995; Corbi et al. 2018; Wei and Yang 2010). Once fertilizers are not sufficiently purified during industrial processes, they usually contain several impurities, including metals and heavy metals (Gimeno-García et al. 1996), such as lead (Pb), cadmium $(\mathrm{Cd})$, copper $(\mathrm{Cu})$, zinc $(\mathrm{Zn})$, chrome $(\mathrm{Cr})$, manganese $(\mathrm{Mn})$, iron $(\mathrm{Fe})$ and nickel $(\mathrm{Ni})$ that are potentially harmful to the environment (Corbi et al. 2018). Although nitrogen and potassium-based fertilizers are not considered a source of metals (McBride and Spiers 2001), phosphate-based fertilizers have been described as a possible origin of such elements in soil (Jiao et al. 2012; Yadav et al. 2010). Several studies have investigated the potential of fertilizers to increase metal concentrations in agricultural soils (Conceição et al. 2009; Marques et al. 2007; Ramalho and Sobrinho 2001). Phosphatic fertilizers such as monoammonium phosphate, diammonium phosphate, and triple superphosphate may contain significant amounts of metals (Kabata-Pendias 2000). The increase in Cd concentration was described as a result of intensive and continuous application of phosphatic fertilizer (Bizarro et al. 2008; Peris et al. 2008; Silva et al. 2016). In fact, small concentrations of metals such as $\mathrm{Cd}$ and $\mathrm{Pb}$ may cause health hazards and decrease the crop yield (Kabata-Pendias 2000).

Sugarcane cultivation usually occurs during five years by planting and ratoon cycles that represent the annual stalk cut and regrowth (Cabral et al. 2020). During this period, sugarcane management includes several agricultural activities, such as soil tillage and organic and inorganic fertilization (Bento et al. 2018). Currently, sugarcane expansion occurs towards the mid-west region of the São Paulo state mainly over extensive pastures (Adami et al. 2012; CONAB 2019; Spera et al. 2017). Extensive pastures are areas destined to livestock production in which no soil tillage or inorganic fertilizations are carried out (Martha Junior et al. 2012). When extensive pastures are converted to sugarcane plantations changes in soil physical and chemical properties are expected as a consequence of soil management to sugarcane cultivation. Soil tillage by plowing and harrowing until 30-cm depth are carried out in the first sugarcane planting. Inorganic fertilization supply nitrogen, phosphorus, potassium and some micronutrients, which are applied inside the sugarcane furrows after soil tillage in the planting, and annually (in the ratoons), over the blanked after stalks harvest (Iamaguti et al. 2015).

Few experiments aimed to better understand the effect of sugarcane cultivation on the accumulation of metals. Some authors reported metal concentrations above the natural in soils cultivated with sugarcane due to inorganic fertilizer applications (Biondi et al. 2011; Bizarro et al. 2008; Corbi et al. 2018), but these experiments did not analyze one complete sugarcane cycle in a conversion context.

Considering the previous knowledge about sugarcane soil management and the metal dynamics in soil, it is hypothesized that sugarcane cultivation would result in changes of soil metal concentrations. Therefore, this research aimed to quantify the soil metal concentrations before and after pasture to sugarcane conversion and in the final of a five-year sugarcane cycle, as well as analyze the correlations with physical and chemical properties. Through these data, it will be possible to compare and discuss the concentrations of metal in sugarcane soils in light of the maximum limits established by the Brazilian government, thus providing an environmental approach to a potential negative impact of sugarcane cultivation. There is none experiment in the literature in which the changes in soil metal concentrations after a complete sugarcane cycle cultivated after pasture-to-sugarcane conversion was evaluated.

\section{MATERIAL AND METHODS}

\section{Study area characterization}

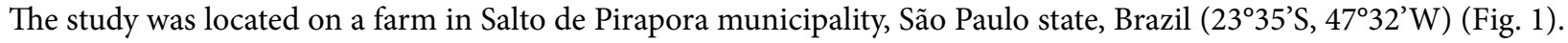
The farm is specialized in the livestock activity that is performed for more than 60 years in an extensive pasture system (low-intensity cattle grazing). The experiment was set up in a local with predominance of Brachiaria sp. The climate in the region is characterized as a Cfa with humid summers and mild to cool winters (Köppen classification). The annual means of maximum and minimum air temperature are 12 and $30^{\circ} \mathrm{C}$, observed respectively in the winter and summer, and annual mean is $21^{\circ} \mathrm{C}$ (Ikematsu et al. 2007). The annual mean precipitation is of $1,330 \mathrm{~mm}$ (Brazilian National Institute for Meteorology, www.inmet.gov.br). The evaluated period follows the expected seasonality patter to air temperature and precipitation (Fig. 1). The soil of the experimental area had a very deep profile, located in a low waved relief and with an 
average elevation of $670 \mathrm{~m}$ (slope of 6.5\%). The soil color was defined as Dark Reddish Brown (2.5YR 2.5/4) (Munsell Color 2010). According to Santos et al. (2018), the soil had clayey texture and was classified as latosol (typical LVAd1).

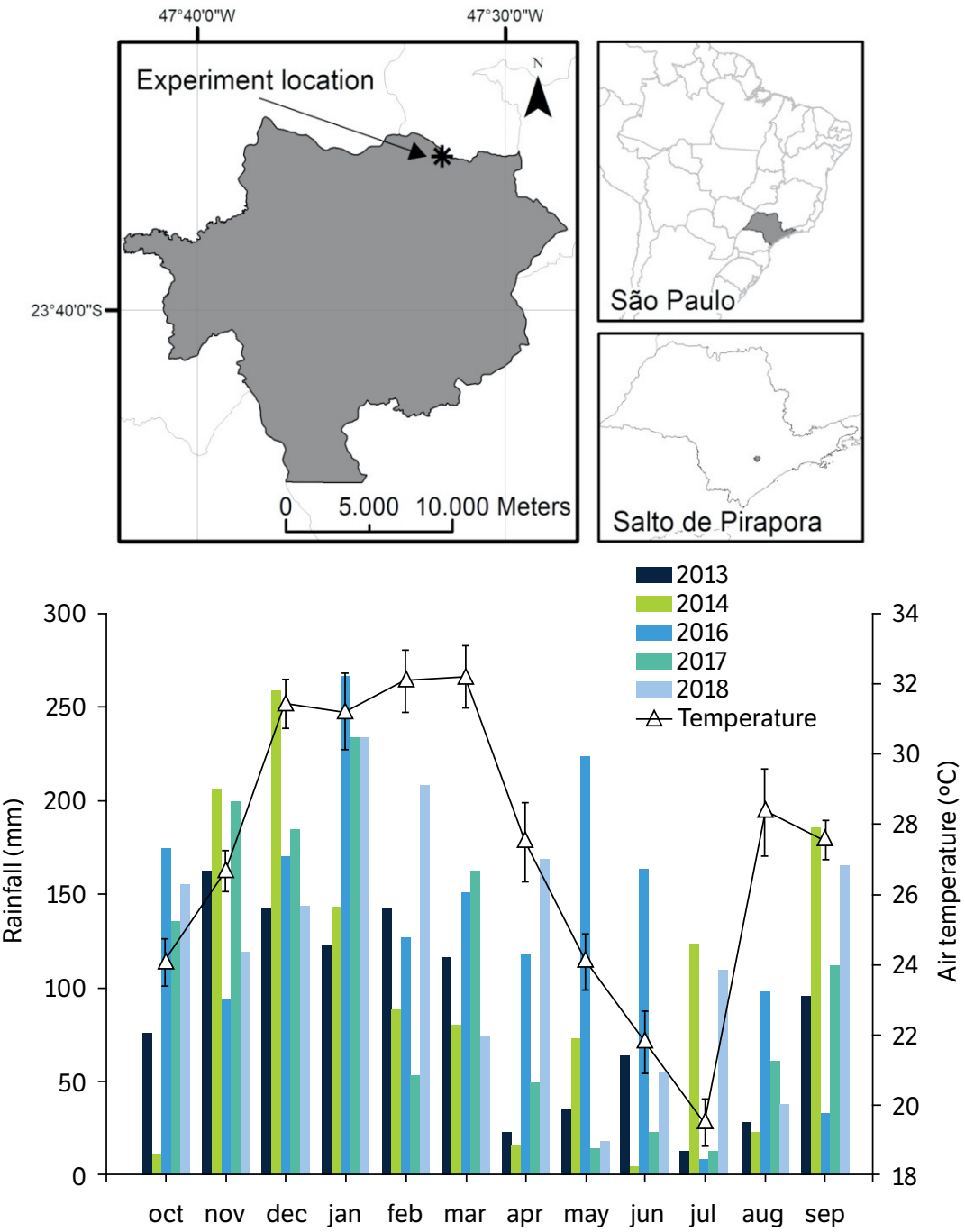

Figure 1. Experimental area location, annual rainfall and air temperature from 2013 to 2018.

\section{Soil management}

The extensive pasture was converted to sugarcane in October 2013. Firstly, conventional soil tillage was carried out in an area of approximately $0.5 \mathrm{ha}$. Tillage operations included double plowing with heavy machinery, harrowing and leveling to open furrows with $30 \mathrm{~cm}$ depth along rows $1.6 \mathrm{~m}$ apart. After tillage, the sugarcane variety RB86-7515 was planted by burying stalks $\left(17 \mathrm{t} \cdot \mathrm{ha}^{-1}\right)$. Then, the furrows were manually inorganic fertilized. The lime application was not necessary, once the initial $\mathrm{pH}$ and bases saturation were ideal considering the levels for agricultural activities (Malavolta 2006).

At the end of the first year of growth season (2014), period named cane-plant, sugarcane stalks were harvested and a new inorganic fertilizer application was carried out. From 2015 to 2018 growing seasons, period named ratoons, inorganic fertilizations were carried out also in the sugarcane rows, but over the soil covered with sugarcane trash (blanked). Considering the five-year sugarcane cycle, the harvesters and inorganic fertilizations were carried out manually every October. Fertilizations followed the rates recommended for sugarcane (van Raij et al. 1997) (Table 1). Total amounts of 
inorganic fertilizer were 188,778 and $200 \mathrm{~kg} \cdot \mathrm{ha}^{-1} \cdot \mathrm{year}^{-1}$ in the cane-plant and 375,158 , and $200 \mathrm{~kg} \cdot \mathrm{ha}^{-1} \cdot \mathrm{year}^{-1}$ in the ratoon cycles of ammonium nitrate, simple superphosphate and potassium chloride, respectively.

Table 1. Treatments identification and soil management of pasture-to-sugarcane conversion.

\begin{tabular}{|c|c|c|c|c|c|c|}
\hline \multirow[t]{2}{*}{ Treatments $^{1}$} & \multirow[t]{2}{*}{ ID } & \multirow{2}{*}{$\begin{array}{l}\text { Sampling } \\
\text { periods }^{2}\end{array}$} & \multirow[t]{2}{*}{ Tillage $^{3}$} & \multicolumn{3}{|c|}{$\begin{array}{c}\text { Fertilization } \\
\left(\mathbf{k g} \cdot \text { ha }^{-1} \cdot \text { year }^{-1}\right)\end{array}$} \\
\hline & & & & $\mathbf{N}$ & $\mathrm{P}_{2} \mathrm{O}_{5}$ & $\mathrm{~K}_{2} \mathrm{O}$ \\
\hline Extensive pasture & EP & Initial condition & No & - & - & - \\
\hline Sugarcane fertilized & $\mathrm{CP}$ & Cane-plant & Yes & 60 & 140 & 120 \\
\hline Sugarcane control in row & $\mathrm{SC}_{\mathrm{R}}$ & Fifth ratoon & Yes & 120 & 30 & 120 \\
\hline Sugarcane fertilized in row & $\mathrm{SF}_{\mathrm{R}}$ & Fifth ratoon & Yes & 120 & 30 & 120 \\
\hline Sugarcane control in mid-row & $\mathrm{SC}_{\mathrm{MR}}$ & Fifth ratoon & Yes & 120 & 30 & 120 \\
\hline Sugarcane fertilized mid-row & $\mathrm{SF}_{\mathrm{MR}}$ & Fifth ratoon & Yes & 120 & 30 & 120 \\
\hline
\end{tabular}

${ }^{1}$ Each one with four replicates and plots of $80 \mathrm{~m}^{2}$ containing a central trench measuring $80 \mathrm{~cm}$ length $\times 80 \mathrm{~cm}$ width $\times 50 \mathrm{~cm}$ depth. ${ }^{2}$ The initial metal concentrations and soil parameters were sampled in September, 2013 (initial concentration), in October, 2014 (cane-plant) and in October, 2018 (fifth ratoon). ${ }^{3}$ The soil tillage was carried out in 2013 including double plowing with heavy machinery, harrowing and leveling. ${ }^{4}$ The nutrient rates were calculated follow Raij et al. (1997). Nutrient sources were: ammonium nitrate $\left(\mathrm{NH}_{4} \mathrm{NO}_{3}\right)$, simple superphosphate, and potassium chloride $(\mathrm{KCl})$ which contain $32 \% \mathrm{~N}, 19 \% \mathrm{P}_{2} \mathrm{O}_{5}$ and $60 \% \mathrm{~K} 2 \mathrm{O}$.

\section{Experimental design}

The treatments were defined based on three pasture-to-sugarcane conversion periods: initial condition, cane-plant (first growth season) and fourth ratoon (last growth season) (Table 1). These periods were established as a chronosequence of the conversion process. The treatments were (i) extensive pasture, which was the land-use before the conversion to sugarcane and provided the initial metal concentrations $(n=4)$; (ii) row of fertilized cane-plant $(n=4)$; (iii) row of unfertilized sugarcane planting at the fourth ratoon (row control plots) $(\mathrm{n}=4)$; (iv) row of fertilized sugarcane at the fourth ratoon $(\mathrm{n}=4)$; (v) mid-row of unfertilized sugarcane planting at the fourth ratoon (mid-row control plots) $(\mathrm{n}=4)$; (vi) mid-row of fertilized sugarcane planting at the fourth ratoon $(\mathrm{n}=4)$. The plots of sugarcane and pasture had $80 \mathrm{~m}^{2}$, distant $6 \mathrm{~m}$ from one to another. The sugarcane plots were delimited soon after soil preparation. Despite the plots had remained in the experimental area during the total experimental period (from 2013 to 2018), there were not simultaneous samplings in the plots.

\section{Soil sampling and physical and chemical analyses}

Soil samples were collected for particle-size distribution, bulk density, soil $\mathrm{pH}$, total carbon and nitrogen, organic matter and metal quantification along the three periods. Trenches measuring $80 \times 80 \times 50 \mathrm{~cm}$ (length, width and depth, respectively) were opened in the middle of each experimental plot. Firstly, soil samples were collected from trenches in the extensive pasture plots in September 2013. The soil was managed to sugarcane plantation (October 2013) and a second soil sampling was performed in the final of the cane-plant period, in October 2014. Soil samples were collected in the rows during the cane-plant period once the first fertilizer application was carried out inside the sugarcane furrows. Finally, soil samples were collected five growth seasons after pasture-to-sugarcane conversion, in October 2018.

Soil samples were collected in two depths, from 0 to 20 and from 20 to $40 \mathrm{~cm}$. To particle-size distribution analyses, four simple soil samples were collected from each plot and were mixed and homogenized to obtain one composite deformed sample. To bulk density determinations, four undeformed soil samples were collected from each face of the trench using standard stainless-steel cylinders $\left(104 \mathrm{~cm}^{3}\right)$. The particle-size distribution was determinate by the pipette method and soil density by bulk density method followed the standard protocols (Camargo et al. 2009). To quantify soil pH, total carbon and nitrogen, organic matter and metal concentrations, soil samples were collected using PVC pipes $(2.5 \mathrm{~cm}$ width and $20 \mathrm{~cm}$ length). One pipe was used to collect four soil samples from the trenches in each of the two depths analyzed. After being collected, the four samples were mixed in polyethylene bags hermetically sealed to form one composite deformed soil 
sample per depth. Pipes and bags were previously washed with tap water and nonionic and metal-free detergent solution, bathed in acid solution $\left(5 \% \mathrm{HNO}_{3}\right)$ for $24 \mathrm{~h}$, and rinsed with distilled water.

Following the protocol for sample preparation and routine laboratory analyses to deformed soil samples, the samples for $\mathrm{pH}$, carbon, nitrogen and metal analyses were homogenized, air dried and sieved through a 2-mm sieve (Camargo et al. 2009). Total carbon and nitrogen were determined by dry combustion in an elementary analyzer (CHNSO analyzer 2400 series II, Perkin Elmer) (Nelson and Sommers 1996). Determinations of $\mathrm{pH}$ were done with $0.01 \mathrm{~mol} \cdot \mathrm{L}^{-1} \mathrm{CaCl}_{2}$ using a bench pH meter (Bel Engineering PHS3BW) (Silva 2009). Organic matter was determinate by colorimetry in a microplate reader (Sinergy HTX Biotech) (Silva 2009).

The method 3051A (USEPA 2007a) was used to process the soil samples collected to metal quantification. Aliquots of $0.5 \mathrm{~g}$ of each soil sample were weighed and submitted to microwave-assisted acid digestion (Multiwave Pro, Anton Paar). The digestion was carried out with three technical replicates. After the microwave-assisted acid digestion, the extracts were transferred to conical centrifuge tubes and centrifuged at $2000 \times \mathrm{g}$ for $10 \mathrm{~min}$ at room temperature $\left(\sim 24^{\circ} \mathrm{C}\right)$. The suspension was transferred to volumetric flasks and filled with ultrapure water to obtain a final volume of $10 \mathrm{~mL}$ for fertilizers and $25 \mathrm{~mL}$ for soil extracts. Glassware was cleaned in $10 \% \mathrm{HNO}_{3}$ solution for $24 \mathrm{~h}$ and rinsed with distilled water.

The $\mathrm{Cr}, \mathrm{Mn}, \mathrm{Fe}, \mathrm{Co}, \mathrm{Ni}, \mathrm{Cu}, \mathrm{Zn}, \mathrm{Mo}, \mathrm{Cd}$ and $\mathrm{Pb}$ quantifications were carried out by microwave plasma atomic emission spectrometry (MP-AES 4200, Agilent Technologies). Analytical calibrations were carried out using multielement standard solution (Agilent Technologies). The wavelengths, limits of detection (LOD) and quantification (LOQ) (Hage and Carr 2012) are described in Table 2 . All reagents used had a high purity rate, and their trace metal content was verified. Ultrapure water for elemental trace analysis was used to prepare the solutions.

Table 2. Wavelength of metal analysis by microwave plasma atomic emission spectrometry (MP-AES) and their limits of detection (LOD) and quantification (LOQ).

\begin{tabular}{cccc}
\hline Element & Wavelength $(\mathbf{n m})$ & LOD $\left(\mathbf{m g} \cdot \mathbf{L}^{-1}\right)$ & LOQ $\left(\mathbf{m g} \cdot \mathbf{L}^{-1}\right)$ \\
\hline $\mathrm{Cr}$ & 425.433 & $6.44 \mathrm{E}-06$ & $1.95 \mathrm{E}-05$ \\
\hline $\mathrm{Mn}$ & 403.076 & $6.27 \mathrm{E}-06$ & $1.90 \mathrm{E}-05$ \\
\hline $\mathrm{Mo}$ & 379.825 & $9.02 \mathrm{E}-07$ & $2.73 \mathrm{E}-06$ \\
\hline $\mathrm{Fe}$ & 371.993 & $2.63 \mathrm{E}-05$ & $7.98 \mathrm{E}-05$ \\
\hline $\mathrm{Cu}$ & 327.395 & $5.40 \mathrm{E}-07$ & $1.64 \mathrm{E}-06$ \\
\hline $\mathrm{Ni}$ & 352.454 & $5.86 \mathrm{E}-07$ & $1.78 \mathrm{E}-06$ \\
\hline $\mathrm{Co}$ & 340.512 & $6.60 \mathrm{E}-06$ & $2.00 \mathrm{E}-05$ \\
\hline $\mathrm{Zn}$ & 213.857 & $6.66 \mathrm{E}-06$ & $2.02 \mathrm{E}-05$ \\
\hline $\mathrm{Cd}$ & 228.802 & $5.89 \mathrm{E}-07$ & $1.78 \mathrm{E}-06$ \\
\hline $\mathrm{Pb}$ & 405.781 & $1.75 \mathrm{E}-05$ & $5.30 \mathrm{E}-05$
\end{tabular}

\section{Metal quantifications in the inorganic fertilizers}

The metal contents in the inorganic fertilizers applied over the soil of the experimental area were verified once it was the main anthropogenic source of metals during the experimental period. Samples of ammonium nitrate, superphosphate simple and potassium chloride, applied in the experimental plots, were separated and smashed for metal concentration analysis. One same batch of inorganic fertilizer, acquired in 2013, was used during the entire experimental period.

Aliquots of $0.25 \mathrm{~g}$ of each fertilizer source were weighed. Samples were subjected to microwave-assisted acid digestion following the method proposed by Lorençatto (2019). The digestion was carried out with three technical replicates. After fertilizer microwave-assisted acid digestion, the same methodology carried out to soil extracts was performed. Differently of soil, to fertilizer metal quantifications the final volume of the extracts was of $10 \mathrm{~mL}$. 


\section{Statistical analysis}

The descriptive statistics were determined through the mean, minimum, maximum and coefficient of variation for the metal concentrations in the treatments. The normality of the data was analyzed through the Shapiro-Wilk test. Significant differences $(\mathrm{p}<0.05)$ were verified to the soil metal concentrations and to the soil physical and chemical properties. They were determinate through two-way analysis of variance (ANOVA), considering as factor the treatments and depth, as well as the interactions between these factors. The correlation between the soil metal concentrations and the soil physical and chemical properties were analyzed by Pearson's test $(\mathrm{p}<0.05)$. The PCA was used to explore the relationships between metal concentration data and the physical and chemical properties, with data normalization by autoscaling and Euclidean distance. Analyses were performed in RStudio software (R 3.4.1) (https://cran.r-project.org) and MINITAB 14.0 software.

\section{RESULTS AND DISCUSSION}

\section{Soil physical and chemical properties}

Conventional management systems can influence on soil physical and chemical properties of several crops. Changes in soil physical and chemical conditions resulted from the agricultural activity are controlled by the tillage, input of plant residues, chemical composition and decomposition of organic matter, rainfall, soil moisture and temperature, $\mathrm{pH}$, and microorganism activity (Bayer et al. 2000; Bronick and Lal 2005; Dieckow et al. 2009; Lal 2004; Reynolds et al. 2007). As expected for the soil type, particle-size distribution showed that the soil in the experimental area had highest clay content comparing with sand and the soil texture was mainly clayey (Table 3). Bulk density remained next to the initial observation only when CP was taken into consideration (Table 3). Reynolds et al. (2007) classify the soil bulk density in three categories (I, II, and III), the sugarcane data falls mainly on category III (BD > $1.2 \mathrm{~g} \cdot \mathrm{dm}^{-3}$ ), which indicates high soil compaction conditions. Thus, the sugarcane ratoons reveal an increase in soil compaction.

Table 3. Soil physical and chemical parameters $(n=4)$ in the periods of extensive pasture, cane-plant and fifth sugarcane ratoon.

\begin{tabular}{|c|c|c|c|c|c|c|c|}
\hline Depth (cm) & Sand (\%) & Clay (\%) & $\mathrm{BD}\left(\mathrm{g} \mathrm{dm}^{-3}\right)$ & $\mathrm{pH}$ & $C\left(\mathbf{g} \cdot \mathbf{k g}^{-1}\right)$ & $\mathbf{N}\left(\mathbf{g} \cdot \mathbf{k g}^{-1}\right)$ & $\mathrm{OM}\left(\mathrm{g} \cdot \mathrm{dm}^{-3}\right)$ \\
\hline EP 0-20 & 24.32 & 51.14 & 1.10 & 6.39 & 276.22 & 34.92 & 30 \\
\hline EP 20-40 & 12.51 & 59.11 & 0.94 & 6.12 & 247.78 & 31.18 & 27 \\
\hline CP 0-20 & 15.17 & 58.74 & 1.10 & 5.51 & 297.53 & 16.42 & 34 \\
\hline CP 20-40 & 18.15 & 59.79 & 1.17 & 5.38 & 223.13 & 9.37 & 29 \\
\hline $\mathrm{SC}_{\mathrm{R}} 0-20$ & 20.97 & 54.36 & 1.21 & 6.01 & 289.17 & 48.07 & 73 \\
\hline $\mathrm{SC}_{\mathrm{R}} 20-40$ & 4.70 & 56.09 & 1.20 & 5.76 & 236.23 & 39.36 & 51 \\
\hline $\mathrm{SC}_{\mathrm{MR}} 0-20$ & 18.58 & 53.68 & 1.19 & 6.08 & 284.34 & 46.36 & 73 \\
\hline $\mathrm{SC}_{\mathrm{MR}} 20-40$ & 23.23 & 59.49 & 1.24 & 5.87 & 228.47 & 43.25 & 48 \\
\hline $\mathrm{SF}_{\mathrm{R}} 0-20$ & 16.70 & 57.04 & 1.15 & 5.48 & 331.14 & 44.21 & 70 \\
\hline $\mathrm{SF}_{\mathrm{R}} 20-40$ & 20.65 & 61.63 & 1.38 & 5.57 & 268.70 & 38.67 & 59 \\
\hline $\mathrm{SF}_{\mathrm{MR}} 0-20$ & 17.88 & 64.81 & 1.21 & 5.51 & 343.88 & 53.76 & 71 \\
\hline $\mathrm{SF}_{\mathrm{MR}} 20-40$ & 15.01 & 57.51 & 1.30 & 5.58 & 232.92 & 38.35 & 55 \\
\hline
\end{tabular}

$\mathrm{EP}=$ initial conditions of the experimental area; $\mathrm{CP}=$ cane-plant; $\mathrm{SC}_{\mathrm{R}}$ and $\mathrm{SC}_{\mathrm{MR}}=$ row and mid-row of unfertilized sugarcane on the fifth ratoon cycle, respectively; $\mathrm{SF}_{\mathrm{R}}$ and $\mathrm{SF}_{\mathrm{MR}}=$ row and mid-row of fertilized sugarcane on the ratoon cycle, respectively. $\mathrm{BD}$ = bulk density; OM: organic matter (colorimetric).

The $\mathrm{pH}$ decreased from the EP to the CP, SC and SF treatments. Soil $\mathrm{pH}$ is also an important parameter for the transport and destination of metals, and its ionization, water solubility and mobility increase at low soil pH (Omwoma et al. 2010). High soil pH, which is slightly alkaline, is responsible for decreasing the mobility of metals in soils (Keshavarzi and Kumar 
2020). The data revealed an increase in soil acidity over the years of sugarcane cultivation, resulting in a reduction in metal adsorption (Table 3).

After soil management, the carbon contents at $20-40 \mathrm{~cm}$ decreased when compared with the initial levels, excluding the sugarcane in rows at the fifth ratoon. The carbon contents at the $0-20 \mathrm{~cm}$ depth increase substantially mainly at the fifth ratoon. During the CP, the total nitrogen contents decreased at 0-20 and 20-40 cm soil depths. The highest carbon and nitrogen contents were observed at $0-20 \mathrm{~cm}$ on rows and mid-rows in the fifth sugarcane ratoon (Table 3). Soil tillage and organic matter deposition (sugarcane trash) influence on organic matter decomposition and carbon contents (Graham and Haynes 2006; Teixeira et al. 2010). When the soil was revolved, the aggregates are exposed and microorganism activity is promoted, favoring the organic matter mineralization of the more labile fractions and decreasing carbon accumulation (Paustian et al. 2000). A high $\mathrm{C} / \mathrm{N}$ relationship of the litter formed by the sugarcane cultivation and the nitrogen fertilizations can reflect on the larger carbon and nitrogen contents. Organic matter consumption by microorganisms results in a lower potential for carbon (Bronick and Lal 2005; Reicosky et al. 1997), but if mineralization rates are slow, a carbon accumulation can be observed.

The results of chemical characterization showed that organic matter rose by $\sim 12 \%$ in $\mathrm{CP}$ and $\sim 71 \%$ in SF, considering the initial condition and the first $0-20 \mathrm{~cm}$ results (Table 3 ). The organic matter tends to accumulate in the first soil layers because of the sugarcane blanket that is deposited and transformed on the soil surface (Wood 1991). Organic matter influences the transport of metals in soil, and anthropogenic additions could be strongly correlated with soil organic carbon (Omwoma et al. 2010). The increases in the carbon and nitrogen contents and the organic matter content from 2013 to 2018 (Table 3) increased the complexation of the metals on soil solution (Gharaibeh et al. 2020).

\section{Metal concentration in soil}

The means of metal concentration occurred according to the following order: $\mathrm{Cd}<\mathrm{Pb}<\mathrm{Cu}<\mathrm{Zn}<\mathrm{Cr}<\mathrm{Mn}<\mathrm{Fe}$ (Fig. 2). The elements Mo, Ni and Co remain well marked below the detection limit during the soil analyses. The coefficient of variation values for the metals in soil ranged from 0.81 to $152.25 \%$. The Fe presented the lowest coefficient of variation, suggesting low variation among soil samples, while $\mathrm{Cd}$ had the highest, suggesting more variation among soil samples and a high likelihood of an anthropogenic effect (Cai et al. 2015; Chen et al. 2008; Keshavarzi and Kumar 2020). A coefficient of variation of $30-50 \%$ or more is common for many metals in soils when sampling is carried out randomly (Gharaibeh et al. 2020).

Despite significant differences in the Cr soil concentrations not being observed, either by treatments or depth, there was an apparent effect of soil tillage in increase $\mathrm{Cr}$ concentrations (Table 4; Fig. 2). It is possible to infer that the differences in the amount of $\mathrm{Cr}$ were observed due to an acceleration of organic matter mineralization by tillage, blanket accumulation and high clay amounts, even such difference did not result in statistical significance. The correlation between $\mathrm{Cr}$ and $\mathrm{Fe}$ (Table 5) may be explained by the fact that, in the presence of iron oxides, the speciation of $\mathrm{Cr}$ in soil is positively affected (USEPA 2008). Camilotti et al. (2009) observed Cr oscillations from 26.08 to $39.75 \mathrm{mg} \cdot \mathrm{kg}^{-1}$, while Lake (1987) observed differences from 5 to $1000 \mathrm{mg} \cdot \mathrm{kg}^{-1}$. However, Barceló and Poschenrieder (1992) mentioned normal contents of $50 \mathrm{mg} \cdot \mathrm{kg}^{-1}$, which is similar with the contents observed in this experiment.

The Mn soil concentrations were significantly different among the depths, but no significant differences were observed when the effect of treatments was considered (Table 4; Fig. 2). The Mn soil concentration in EP at $0-20 \mathrm{~cm}$ depth was the highest among the treatments (Fig. 2). For the same element, the concentrations $(0-20 \mathrm{~cm})$ were not different in the $\mathrm{CP}$, $\mathrm{SF}_{\mathrm{R}}$ and $\mathrm{SF}_{\mathrm{MR}}$ treatments and were lowest than those observed in the control $\left(\mathrm{SC}_{\mathrm{R}}\right.$ and $\mathrm{SC}_{\mathrm{MR}}$ ) and $\mathrm{EP}$ treatments (Fig. 2). The Mn maintenance in soil is also due to the organic matter provided by the blanket above superficial depth $(0-20 \mathrm{~cm})$, this condition can be clearly verified through the increase in organic matter content (Table 3 ) and through the significant correlations between carbon content and Mn (Table 5). 

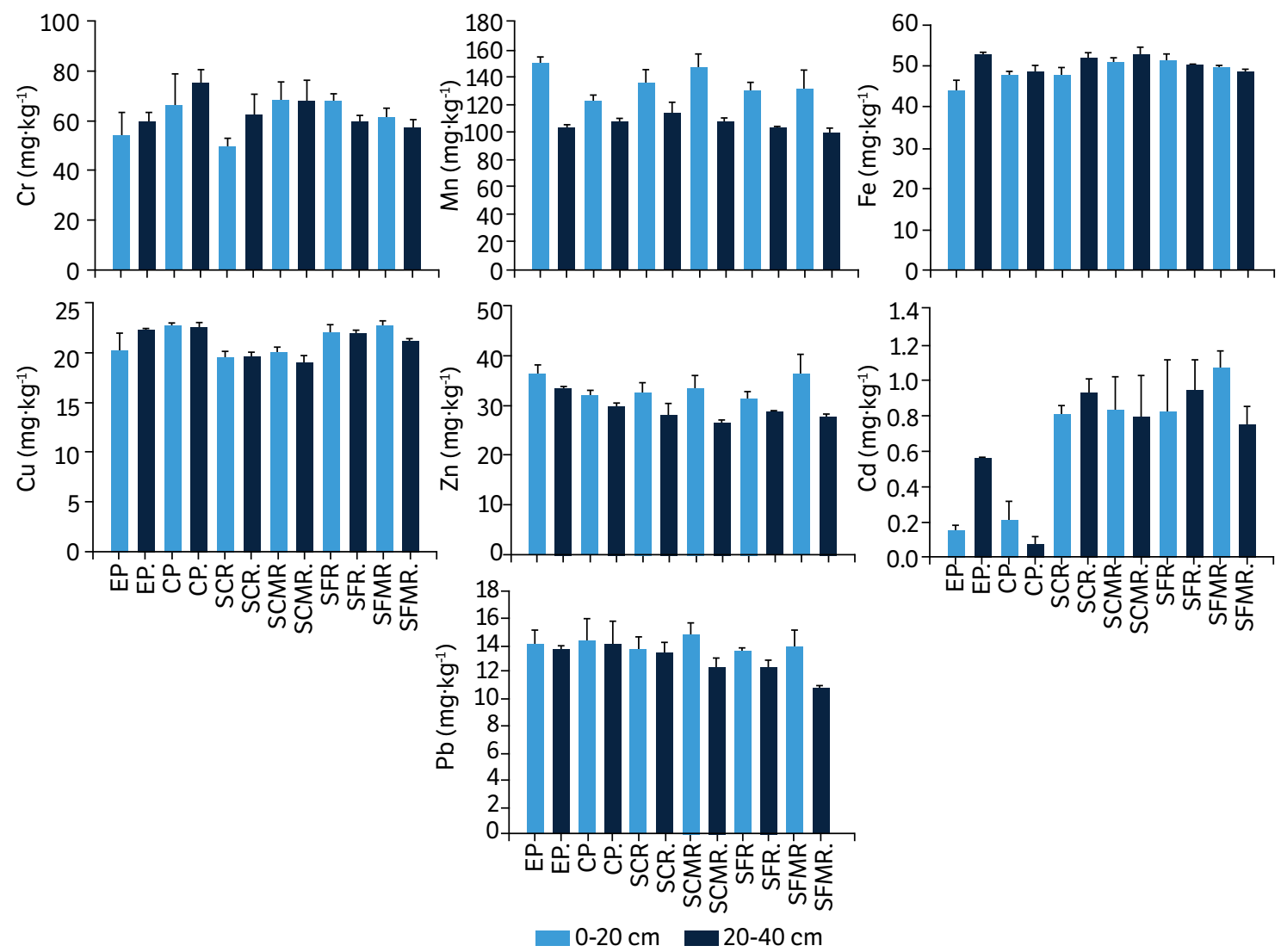

Figure 2. Soil metal concentrations in the periods of extensive pasture, cane-plant and fifth sugarcane ratoon.

Note. Treatments were named as following: $\mathrm{EP}=$ initial conditions of the experimental area; $\mathrm{CP}=$ cane-plant; $\mathrm{SC}_{\mathrm{R}}$ and $\mathrm{SC}_{\mathrm{MR}}=$ row and mid-row of unfertilized sugarcane on the fifth ratoon cycle, respectively; $\mathrm{SF}_{\mathrm{R}}$ and $\mathrm{SF}_{\mathrm{MR}}=$ row and mid-row of fertilized sugarcane on the fifth ratoon cycle, respectively.

Table 4. Effect of treatment, depth, inorganic fertilization and time on soil metal concentration and in soil physical and chemical properties measure by two-way analysis of variance.

\begin{tabular}{|c|c|c|c|}
\hline & Treatments $^{1}$ & Depth & Interactions \\
\hline \multicolumn{4}{|c|}{ Soil metal concentrations } \\
\hline $\mathrm{Cr}$ & ns & ns & ns \\
\hline $\mathrm{Mn}$ & ns & $p<0.05$ & ns \\
\hline $\mathrm{Fe}$ & ns & ns & $p<0.05$ \\
\hline $\mathrm{Cu}$ & $\mathrm{p}<0.001$ & ns & ns \\
\hline $\mathrm{Zn}$ & ns & $p<0.001$ & ns \\
\hline $\mathrm{Cd}$ & $p<0.001$ & ns & ns \\
\hline $\mathrm{Pb}$ & ns & $p<0.05$ & ns \\
\hline \multicolumn{4}{|c|}{ Physical and chemical properties } \\
\hline $\mathrm{pH}$ & $p<0.001$ & ns & $p<0.05$ \\
\hline Sand & ns & ns & ns \\
\hline Clay & ns & ns & $p<0.05$ \\
\hline C & $p<0.05$ & $p<0.05$ & $p<0.05$ \\
\hline $\mathrm{N}$ & $p<0.001$ & $\mathrm{p}<0.001$ & $\mathrm{p}<0.001$ \\
\hline OM & $p<0.001$ & $p<0.05$ & ns \\
\hline
\end{tabular}

${ }^{1}$ Treatments (EP, $C P, \mathrm{SC}_{\mathrm{R}}, \mathrm{SC}_{\mathrm{MR}}, \mathrm{SF}_{\mathrm{R}}$ and $\mathrm{SF}_{\mathrm{MR}}$ ) were designed to test fertilization (control and fertilized), row position (row and mid row) and period (extensive pasture, cane-plant and fifth ratoon). 
Table 5. Pearson's correlation matrix and the significance level of metals and the soil physical-chemical parameters. We considered correlation results of $0.40-0.59$ as moderate correlation and $>0.60$ as strong correlation.

\begin{tabular}{|c|c|c|c|c|c|c|c|c|c|c|c|c|}
\hline & $\mathrm{Zn}$ & Cd & $\mathrm{Cu}$ & $\mathrm{Pb}$ & $\mathrm{Mn}$ & $\mathrm{Cr}$ & $\mathrm{Fe}$ & Sand & Clay & C & $\mathbf{N}$ & $\mathrm{pH}$ \\
\hline $\mathrm{Zn}$ & - & & & & & & & & & & & \\
\hline $\mathrm{Cd}$ & -0.13 & - & & & & & & & & & & \\
\hline $\mathrm{Cu}$ & $0.31^{\star}$ & -0.04 & - & & & & & & & & & \\
\hline $\mathrm{Pb}$ & $0.58^{\star \star \star}$ & -0.09 & 0.15 & - & & & & & & & & \\
\hline $\mathrm{Mn}$ & $0.60^{\star \star \star}$ & -0.08 & -0.06 & $0.45^{\star \star}$ & - & & & & & & & \\
\hline $\mathrm{Cr}$ & 0.05 & 0.06 & 0.20 & 0.21 & -0.02 & - & & & & & & \\
\hline $\mathrm{Fe}$ & -0.22 & $0.51^{\star \star \star}$ & 0.16 & -0.04 & $-0.30^{\star}$ & $0.40^{\star \star}$ & - & & & & & \\
\hline Sand & 0.20 & 0.01 & -0.02 & 0.021 & $0.31^{\star}$ & $-0.30^{\star}$ & -0.23 & - & & & & \\
\hline Clay & 0.02 & 0.21 & $0.42^{\star \star}$ & -0.04 & $-0.38^{\star \star \star}$ & 0.14 & $0.47^{\star \star \star}$ & 0.009 & - & & & \\
\hline C & $0.36^{\star}$ & 0.18 & -0.09 & 0.27 & $0.62^{\star \star \star}$ & 0.03 & -0.02 & 0.21 & $-0.36^{\star}$ & - & & \\
\hline $\mathrm{N}$ & 0.12 & $0.68^{\star \star \star}$ & -0.24 & -0.12 & $0.31^{\star}$ & -0.06 & 0.23 & -0.11 & -0.16 & $0.48^{\star \star \star}$ & - & \\
\hline $\mathrm{pH}$ & 0.20 & -0.10 & $-0.27^{\star}$ & 0.11 & $0.39^{\star \star}$ & -0.21 & -0.22 & $0.25^{\star}$ & $-0.41^{\star \star}$ & 0.19 & 0.19 & - \\
\hline
\end{tabular}

The Fe soil concentrations did not present significant differences, but the interactions between treatments and depth result in differences (Table 4; Fig. 2). As expected, Fe concentrations were the highest between the elements analyzed and was positively correlated with clay contents (Table 5). At the 0-20 cm soil depth, Fe correlations with clay can explain greater iron contents, but organic matter mineralization in this soil layer is also an important factor to take into account, which corroborates with the highest Fe levels in $\mathrm{SF}_{\mathrm{R}}$. It can be observed that, where the clay concentrations were higher (Table 3), Fe levels were also higher (Fig. 2).

The $\mathrm{Cu}$ soil concentrations were significantly different among row position, fertilization and periods; however, they were not different when depth was considered (Table 4; Fig. 2). The lowest $\mathrm{Cu}$ amounts in the $\mathrm{SC}_{\mathrm{R}}$ and $\mathrm{SC}_{\mathrm{MR}}$ were observed when compared with SFR and SFMR. This result can be attributed to the low amount of organic matter and clay in the control treatments, characteristics that demonstrate the mechanism of Cu exchange and adsorption in soil (USEPA 2007b). Moreover, the clay mineral exchange phase may serve as a sink for $\mathrm{Cu}$ in soils (Mclean and Bledsoe 1992). Corroborating the abovementioned results, Cu was significantly correlated with clay $(\mathrm{p}<0.01)$ (Table 5).

The Zn soil concentrations was significantly different among the depths; however, they were not different when the different treatments were considered (Table 4; Fig. 2). Despite the observation that there was a $\mathrm{Zn}$ accumulation effect in the final ratoon cycle at 0-20 cm depth (Fig. 2), the statistical test applied in the data resulted in no significant differences between the treatments. Except for $\mathrm{SF}_{\mathrm{R}}$ treatment, low $\mathrm{Zn}$ amounts were observed in soil with low $\mathrm{pH}$; the adsorption by soil compounds occurs at pH 5.0 or greater (USEPA 2007c). At the $0-40 \mathrm{~cm}$ soil layer depth, $\mathrm{Zn}$ concentrations decreased consecutively, while clay amounts were major. According to the literature, zinc is readily adsorbed by clay minerals when associated with Fe and $\mathrm{Mn}$ oxides (USEPA 2007b), this information corroborates the results, in which Zn was significantly correlated with Mn (Table 5).

The Cd concentrations were not different at depths of 0-20 and 20-40 cm, but were significantly different when row position, fertilizer application and periods were taking into account (Table 4; Fig. 2). In sugarcane rows and midrows, at the fourth ratoon, there was an increase in Cd concentration. In the rows, there were no differences between the unfertilized $\left(\mathrm{SC}_{\mathrm{R}}\right)$ and fertilized $\left(\mathrm{SF}_{\mathrm{R}}\right)$ treatments (Fig. 2). Similarly, in mid-rows at the fourth ratoon, the means were not different in the unfertilized $\left(\mathrm{SC}_{\mathrm{MR}}\right)$ and fertilized $\left(\mathrm{SF}_{\mathrm{MR}}\right)$ treatments at $20-40 \mathrm{~cm}$ depth but were different at $0-20 \mathrm{~cm}$ depth (Fig. 2). The reduction in Cd concentration at deeper depths after conversion of pasture-to-sugarcane occurred likely due to the soil management to sugarcane planting. In rows, the increase in $\mathrm{Cd}$ concentrations was caused by organic matter and $\mathrm{pH}$ alterations, as well as by interactions with other elements that became the metal available. The Cd concentration in SFMR at the 0-20 cm soil was higher than in $\mathrm{CP}$, $\mathrm{EP}$, and $\mathrm{SC}_{\mathrm{MR}}$. The $\mathrm{Cd}$ was $0.23 \mathrm{mg} \cdot \mathrm{kg}^{-1}$ higher than in the respective unfertilized treatment (Fig. 2). 
The $\mathrm{Pb}$ soil concentrations were not significant when row position, fertilization and periods were considered, but the depths result in significant differences (Table 4; Fig. 2). The soil pH varies from 5.0 to 6.5 , and at this condition, the concentration of $\mathrm{Pb}$ in the soil solution reaches a minimum due to metal-organic complex formation (USEPA 2005). Finally, Lake (1987) observed $\mathrm{Pb}$ concentrations ranging from 21.17 to $24.75 \mathrm{mg} \cdot \mathrm{kg}^{-1}$ higher than those observed in this experiment and the ones described as normal (from 12 to $14 \mathrm{mg} \cdot \mathrm{kg}^{-1}$ ) (Oliveira et al. 2005).

The PCA reinforced the differences between the treatments, showed by the statistical analyses. These differences reveal the influence of the fertilizer on change the metal concentrations, which is indicated by the group's separation (Fig. 3). Two different groups containing the soil samples studied are identified. This distribution is explained by $55.4 \%$ of the total data variance, which is the sum of the two principal components (PC1 31.2\% and PC2 24.2\%). Group A is mainly formed by the fertilized treatments $\left(\mathrm{CP}, \mathrm{SF}_{\mathrm{MR}}\right.$ and $\left.\mathrm{SF}_{\mathrm{R}}\right)$, and $\mathrm{Cr}, \mathrm{Fe}$ and $\mathrm{Cd}$ are connected negatively to clay content in this group (Fig. 3). Opposing, group B is formed by the unfertilized treatments (EP, $\mathrm{SC}_{\mathrm{R}}$ and $\mathrm{SC}_{\mathrm{MR}}$ ), and $\mathrm{pH}$ is positively connected with $\mathrm{Zn}, \mathrm{Mn}$, carbon and nitrogen (Fig. 3). The variables sand, $\mathrm{Pb}$ and $\mathrm{Cu}$ did not seem to directly affect the group separation by treatments (Fig. 3).
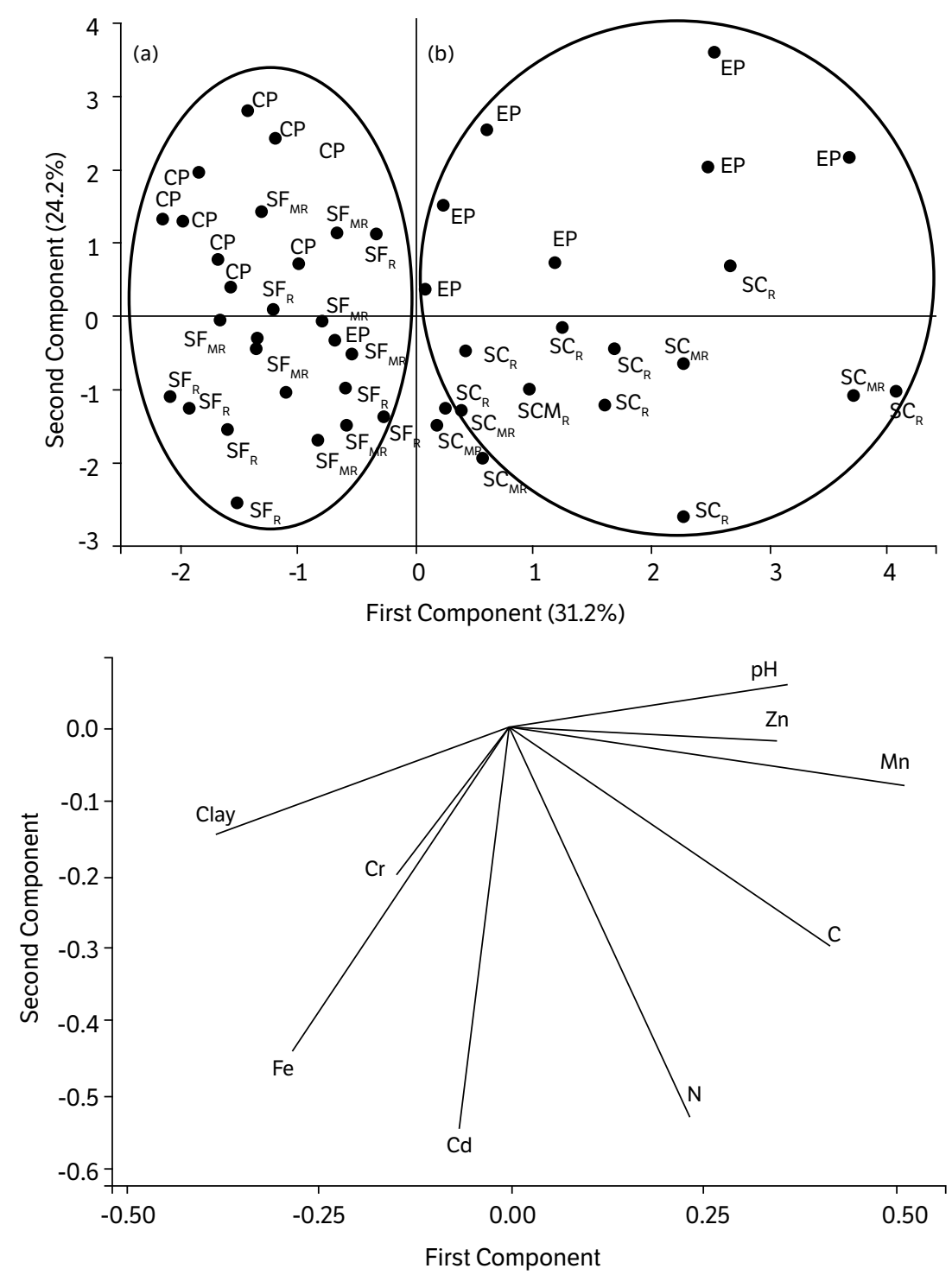

Figure 3. Principal component analysis for samples and parameters distributions along PC1 versus PC2.

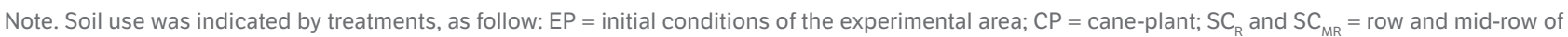
unfertilized sugarcane on the fifth ratoon cycle, respectively; $\mathrm{SF}_{\mathrm{R}}$ and $\mathrm{SF}_{\mathrm{MR}}=$ row and mid-row of fertilized sugarcane on the fifth ratoon cycle, respectively. 
The results of PCA showed that the variables that most included samples after cultivation were $\mathrm{Cd}, \mathrm{Cr}$, $\mathrm{Fe}$ and clay. Groups A and B are formed by samples of fertilized and unfertilized treatments, which shows the influence of the fertilizer application in the accumulation of the metal. In group A, the lower the clay content, the lower the $\mathrm{Cd}, \mathrm{Cr}$ and $\mathrm{Fe}$ concentrations, suggesting that clay could mainly be responsible for metal sorption in the fertilized treatments. Soils with higher clay content retain more metals than light-textured soils (Gharaibeh et al. 2020). Group A also suggests that Cd, $\mathrm{Cr}$ and $\mathrm{Fe}$ are affected by fertilization. In group $\mathrm{B}$, the higher the $\mathrm{pH}$, the lower the $\mathrm{Zn}, \mathrm{Mn}$, carbon and nitrogen contents. Once there were no fertilized and no-tilled (EP) treatments in group B, it could be inferred that $\mathrm{pH}$ was the main factor controlling the variables previously cited.

\section{Metal concentration in fertilizer}

Considering the ten metals analyzed, at least six were found in inorganic fertilizers applied in the experimental area (Table 6). The orders of occurrence of these metals were $\mathrm{Ni}<\mathrm{Cu}<\mathrm{Cr}<\mathrm{Zn}<\mathrm{Mn}<\mathrm{Fe}$ to ammonium nitrate, $\mathrm{Cd}<\mathrm{Co}$ $<\mathrm{Mo}<\mathrm{Ni}<\mathrm{Cr}<\mathrm{Cu}<\mathrm{Zn}<\mathrm{Fe}<\mathrm{Mn}$ to superphosphate simple and $\mathrm{Cd}<\mathrm{Cu}<\mathrm{Pb}<\mathrm{Zn}<\mathrm{Mn}<\mathrm{Cr}<\mathrm{Fe}$ to potassium chloride (Table 6). Brazilian phosphate-based fertilizers, excluding thermophosphate, have low $\mathrm{Cd}, \mathrm{Cr}$ and $\mathrm{Ni}$ amounts (Minari et al. 2017), and the concentrations obtained in this experiment was lower than those observed by other authors, in which they found rates ranging from 3 to $4 \mathrm{mg} \cdot \mathrm{kg}^{-1} \mathrm{Cd}$, from 14 to $26 \mathrm{mg} \cdot \mathrm{kg}^{-1} \mathrm{Cr}$, and from 3 to $45 \mathrm{mg} \cdot \mathrm{kg}^{-1} \mathrm{Ni}$ (Gabe and Rodella 1999).

Table 6. Metal concentrations $(n=4)$ in the inorganic fertilizers and the total element quantities added annually.

\begin{tabular}{|c|c|c|c|c|}
\hline \multirow[b]{2}{*}{ Element } & \multicolumn{3}{|c|}{ Metal concentrations ${ }^{1}$} & \multirow{2}{*}{$\begin{array}{c}\text { Added }^{2} \\
\left(\mathrm{~g} \cdot \mathrm{ha}^{-1} \cdot \mathrm{year}^{-1}\right)\end{array}$} \\
\hline & $\begin{array}{c}\text { AN } \\
\left(\mathrm{mg} \cdot \mathrm{kg}^{-1}\right)\end{array}$ & $\begin{array}{c}\text { SS } \\
\left(\mathbf{m g} \cdot \mathbf{k g}^{-1}\right)\end{array}$ & $\begin{array}{c}\text { PC } \\
\left(\mathbf{m g} \cdot \mathbf{k g}^{-1}\right)\end{array}$ & \\
\hline Mo & - & 3.74 & - & 1.05 \\
\hline $\mathrm{Ni}$ & 0.16 & 4.79 & - & 3.06 \\
\hline Co & - & 3.00 & - & 0.85 \\
\hline $\mathrm{Cd}$ & - & 1.51 & 0.69 & 1.06 \\
\hline $\mathrm{Pb}$ & - & - & 2.09 & 0.42 \\
\hline \multirow[t]{2}{*}{$\mathrm{Cr}$} & 0.40 & 7.69 & 6.83 & 12.22 \\
\hline & $\left(\mathbf{m g} \cdot \mathbf{k g}^{-1}\right)$ & $\left(\mathbf{g} \cdot \mathrm{kg}^{-1}\right)$ & $\left(\mathbf{m g} \cdot \mathbf{k g}^{-1}\right)$ & $\left(\mathbf{k g} \cdot \mathrm{ha}^{-1} \cdot\right.$ year $\left.^{-1}\right)$ \\
\hline $\mathrm{Mn}$ & 1.30 & 562.64 & 4.62 & 461.14 \\
\hline $\mathrm{Fe}$ & 42.78 & 540.36 & 431.35 & 488.98 \\
\hline $\mathrm{Cu}$ & 0.22 & 171.02 & 1.35 & 140.17 \\
\hline $\mathrm{Zn}$ & 1.02 & 266.17 & 2.83 & 218.15 \\
\hline
\end{tabular}

${ }^{1} \mathrm{AN}=$ ammonium nitrate; $\mathrm{SS}=$ superphosphate simple; $\mathrm{PC}=$ potassium chloride. ${ }^{2}$ Considering the sum of the quantities applied annually to fertilizer where the element was identified.

The limit of Cd in Brazilian phosphate-based fertilizers is similar to the European Union and higher than California (USA) standards that allow up to $20 \mathrm{mg} \cdot \mathrm{kg}^{-1} \mathrm{P}_{2} \mathrm{O}_{5}$ and $4 \mathrm{mg} \cdot \mathrm{kg}^{-1}$ per $1 \% \mathrm{P} 2 \mathrm{O} 5$, respectively (Jiao et al. 2012). Considering one of the main metals reported in inorganic fertilizers, $\mathrm{Cd}$ addition was approximately half of that from atmospheric deposition, of $1.9 \mathrm{~g} \cdot \mathrm{ha}^{-1} \cdot \mathrm{year}^{-1}$ (Jiao et al. 2012). Nziguheba and Smolders (2008) estimated that the average Cd input from phosphate-based fertilizers in European countries was $1.6 \mathrm{~g} \cdot \mathrm{ha}^{-1} \cdot \mathrm{year}^{-1}, \sim 34 \%$ over the results of this experiment.

\section{Considerations about changes in metal concentration}

Soil chemical properties (Table 3) can be addressed as the main reason for changes in soil metal concentration and dynamics (Table 5). Taking into account that the initial condition was an extensive pasture, the soil management (tillage 
and fertilization) to sugarcane cultivation appears to result in metal concentration changes only when $\mathrm{Cd}$ and $\mathrm{Cu}$ were considered. Some authors reported concentrations of $\mathrm{Cd}$ and other metals above the natural concentration in soils cultivated with sugarcane due to inorganic fertilizer applications (Biondi et al. 2011; Bizarro et al. 2008; Corbi et al. 2018), but these experiments did not analyze one complete sugarcane cycle or not reported the data considering baseline concentrations. Taking into account the total dry weight of the soil mass sampled in the treatments, extrapolating to a volume of 2,000 $\mathrm{m}^{3}$ $\left(10,000 \mathrm{~m}^{2} \times 0.20 \mathrm{~m}\right)$ and the means of soil bulk density determinations in the treatments, as well as the Cd addictions by fertilizer, was estimated a final soil increase of $9.54 \mathrm{mg} \cdot \mathrm{ha}^{-1} \cdot \mathrm{year}^{-1} \mathrm{Cd}$.

The mobility of $\mathrm{Cd}$ in soils is governed by the soil $\mathrm{pH}$, organic matter content, and components of solid-phase minerals (Tiller 1989). In soils with low $\mathrm{pH}$, the content of organic matter as well as oxides and hydroxides of $\mathrm{Fe}$ and $\mathrm{Mn}$ control the solubility of this element. Under acidic conditions, the solubility of Cd increases, and low adsorption by soil colloids is observed (USEPA 2003). Studies indicate that Cd adsorption correlates most with the charge exchange capacity of the soil, especially when the soil is saturated with divalent charges, which explains, combined with the other parameters mentioned, the correlation with Fe (Table 5) and the grouping in A in PCA (Fig. 3) (Barzegar et al. 2005; Tiller 1989; USEPA 2003). It is well established that the higher the $\mathrm{pH}$, the lower the $\mathrm{Cd}$ concentrations expected (Barzegar et al. 2005). However, it has also been described that at $\mathrm{pH}$ values greater than $6.0, \mathrm{Cd}$ is adsorbed by the soil solid phase, and the solution concentrations are reduced (at pH 6.5, 55\% of Cd is adsorbed by soil colloids) (USEPA 2005). Based on these facts, in EP samples, low amounts of $\mathrm{Cd}$ were found due to a high adsorption rate.

Considering this element, Lake (1987) observed lower concentration in agricultural soil than Campos et al. (2003), ranging from 0.01 to $0.7 \mathrm{mg} \cdot \mathrm{kg}^{-1}$. Other authors also observed higher Cd values than Lake (1987) in Brazilian latosol, as follows: range from 1.07 to $1.26 \mathrm{mg} \cdot \mathrm{kg}^{-1} 1\left(0-60 \mathrm{~cm}\right.$ ) (Juliatti et al. 2002) and a mean of $0.7 \mathrm{mg} \cdot \mathrm{kg}^{-1}$ (Oliveira et al. 2005). Despite this divergence, the results agreed with the literature.

Considering all treatments, the mean Cd concentration is $0.65 \mathrm{mg} \cdot \mathrm{kg}^{-1}$, which is close to the Lake (1987) and Oliveira et al. (2005) observations. The authors found that $\mathrm{Cd}$ concentrations only slightly increased after a long period of continuous fertilization; Richards et al. (1998) and Hejcman et al. (2009) reported no evidence that Cd accumulated in soils after 29 and 75 years of fertilizer application, while Jeng and Singh (1995) observed slight increases in Cd concentrations after 70 years of phosphate fertilizer application.

\section{Environmental risks according to Brazilian polices}

Currently, there are no limits determined by the Brazilian legislation destined to inorganic fertilizer for most of the elements analyzed in this experiment (Brazil 2006) (Table 7). Considering the elements covered by the document $(\mathrm{Cd}, \mathrm{Pb}$ and $\mathrm{Cr}$ ), it was observed that none of them exceed the maximum limits allowed in Brazilian polices even those present in the fertilizer samples. Although the concentrations of metals in the fertilizer samples do not reveal values exceeding the maximum limits allowed by the Brazilian laws, it is important to take into account the presence of metals in other nutrient sources applied over sugarcane soils and the changes in the physical and chemical soil properties which may alter the soil metals availability. These alterations mean a new condition in adsorption, complexation, precipitation, leaching and bioavailability of metals.

Though the concentrations, it was analyzed whether metals reached the prevention or the limit soil range proposed by Brazilian polices (Brazil 2009) and if they were between the background concentrations (Table 7). Although between the background concentrations, $\mathrm{Cd}$ detected in $\mathrm{SF}_{\mathrm{MR}}$ at the $0-20 \mathrm{~cm}$ soil depth almost reached the concentration limit for prevention actions, other $\mathrm{Cd}$ concentrations were below the prevention and investigation levels for agricultural soils. $\mathrm{The} \mathrm{Pb}, \mathrm{Cu}$ and $\mathrm{Zn}$ in the soil reached values below the Brazilian polices determinations. According to the Brazilian legal determinations, the $\mathrm{Cr}$ concentrations were close to the prevention and below the investigation (limit) levels to the agricultural soils. There are no determinations for Mn and Fe concentrations in Brazilian policies, but the results showed that the first was under the background concentration and the second was in the expected range. 
Table 7. Prevention and limit contents in Brazilian latosol designated for agriculture, based on Brazilian laws and national soil background concentrations.

\begin{tabular}{|c|c|c|c|c|}
\hline \multirow{2}{*}{ Element } & \multicolumn{3}{|c|}{ Soil $\left(\mathbf{m g} \cdot \mathbf{k g}^{-1}\right)$} & \multirow{2}{*}{$\begin{array}{c}\text { Fertilizer }\left(\mathrm{mg} \cdot \mathrm{kg}^{-1}\right) \\
\text { Permitted }^{3}\end{array}$} \\
\hline & Prevention $^{1}$ & Limit/Investigation ${ }^{1}$ & Background $^{2}$ & \\
\hline $\mathrm{Mn}$ & ND & ND & $400-700$ & - \\
\hline Mo & 30 & 50 & - & - \\
\hline $\mathrm{Fe}$ & ND & ND & $20,000-550,000$ & - \\
\hline $\mathrm{Cu}$ & 60 & 200 & $3-238$ & - \\
\hline $\mathrm{Ni}$ & 30 & 70 & $3-45$ & - \\
\hline Co & 25 & 35 & $7-10$ & - \\
\hline $\mathrm{Zn}$ & 300 & 450 & $12-96$ & - \\
\hline $\mathrm{Cd}$ & 1.3 & 3 & $0.37-1.01$ & 20 \\
\hline $\mathrm{Pb}$ & 72 & 180 & $10-49$ & 100 \\
\hline
\end{tabular}

${ }^{1}$ Resolution no 420 of 28, December 2009 (Brazil 2009). ${ }^{2}$ The background concentrations of the elements $\mathrm{Cu}$, Ni, Zn, Cd, Pb were defined by Campos et al. (2003); Mn by USEPA (2007); Fe by USEPA (2003); Co by Biondi et al. (2011). ${ }^{3}$ SDA Normative Instruction no. 27 from February, 05 of 2006 (Brazil 2006 ), that considered the maximum limits of metals in mineral fertilizers with nitrogen, potassium and secondary macronutrients with um $5 \%$ of P2O5 and to not specified values. ND = not defined.

\section{CONCLUSION}

After five years of pasture-to-sugarcane conversion, increases in soil metal concentrations as resulted of the management to sugarcane cultivation, which included soil tillage and inorganic fertilization, were significant to $\mathrm{Cd}$ and $\mathrm{Cu}$. After one completed

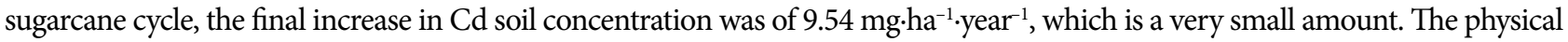
and chemical soil properties presented correlations with all metal concentrations. The significant increases in $\mathrm{Zn}, \mathrm{Pb}$ and $\mathrm{Mn}$ soil concentrations at the 0-20 and 20-40 cm depth were addressed exclusively to the physical and chemical soil properties. Take into account the maximum limits established by the Brazilian polices, the results of this study about the increases in soil metal concentration during sugarcane cultivation did not represent environmental risks when compared with other anthropogenic activities.

\section{AUTHORS' CONTRIBUTION}

Conceptualization: Bento C. B.; Methodology: Camargo L. O.; Investigation: Bento C. B., Gabriel G. V. M., Botero W. G. and Fernandes A. P.; Writing - Original Draft: Bento C. B.; Writing - Review and Editing: Bento C. B., Gabriel G. V. M., Camargo L. O. and Carmo J. B.; Funding Acquisition: Carmo J. B. and Martinelli L. A.; Resources: Camargo L. O. and Carmo J. B.; Supervision: Camargo L. O.

\section{DATA AVAILABILITY STATEMENT}

The data will be available upon request.

\section{FUNDING}

Coordenação de Aperfeiçoamento de Pessoal de Nível Superior

https://doi.org/10.13039/501100002322

Finance Code 001 
Fundação de Amparo à Pesquisa do Estado de São Paulo

https://doi.org/10.13039/501100001807

Grant No. 00771-0/2018, 18790-3/2015

\section{ACKNOWLEDGMENTS}

We thank the Biotechnology and Environmental Monitoring Graduate Program for enabling the use of the MP-AES pro-equipment project (proposal no. 189683) CAPES no. 11/2014.

\section{REFERENCES}

Adami, M., Rudorff, B. F. T., Freitas, R. M., Aguiar, D. A., Sugawara, L. M. and Mello, M. P. (2012). Remote sensing time series to evaluate direct land use change of recent expanded sugarcane crop in Brazil. Sustainability, 4, 574-585. https://doi.org/10.3390/su4040574

Alloway, B. J. (1995). Heavy metals in soils. Berlin: Springer Netherlands.

Appenroth, K.-L. (2010). What are "heavy metals" in plant sciences? Acta Physiologiae Plantarum, 32, 615-619. https://doi.org/10.1007/ s11738-009-0455-4

Barceló, J. and Poschenrieder, C. (1992). Respuestas de las plantas a la contaminación por metales pesados. Suelo y Planta, 2 , $345-361$.

Barzegar, A. R., Koochekzadeh, A., Xing, B. and Herbert, S. J. (2005). Concentration changes of Cd, Ni and Zn in sugarcane cultivated soils. Water, Air, and Soil Pollution, 161, 97-112. https://doi.org/10.1007/s11270-005-2885-y

Bayer, C., Mielniczuk, J., Amadoc, T. J., Martin-Netod, L. and Fernandese, S. V. (2000). Organic matter storage in a sandy clay loam Acrisol affected by tillage and cropping systems in southern Brazil. Soil and Tillage Research, 54, 101-109. https://doi.org/10.1016/ S0167-1987(00)00090-8

Bento, C. B., Filoso, S., Machado, L., Cantarella, H., Rossetto, R., Antonio, L. and Carmo, J. B. (2018). Impacts of sugarcane agriculture expansion over low-intensity cattle ranch pasture in Brazil on greenhouse gases. Journal of Environmental Management, 206, 980-988. https://doi.org/10.1016/j.jenvman.2017.11.085

Biondi, C. M., Nascimento, C. W. A., Fabricio Neta, A. B. and Ribeiro, M. R. (2011). Teores de Fe, Mn, Zn, Cu, Ni E Co em solos de referência de Pernambuco. Revista Brasileira de Ciência do Solo, 35, 1057-1066. https://doi.org/10.1590/S0100-06832011000300039

Bizarro, V. G., Meurer, E. J. and Tatsch, F. R. P. (2008). Teor de cádmio em fertilizantes fosfatados comercializados no Brasil. Ciência Rural, 38, 247-250. https://doi.org/10.1590/S0103-84782008000100041

Brazil. (2006). Instrução Normativa SDA No 27, 05 de junho de 2006. (Alterada pela IN SDA no 7, de 12/04/2016, republicada em 02/05/2016). http://extranet.agricultura.gov.br/sislegis-consulta/consultarLegislacao.do?operacao=visualizar\&id=16951.

Brazil. (2009). Resolução No 420, de 28 de dezembro de 2009. Dispõe sobre critérios e valores orientadores de qualidade do solo quanto à presença de substâncias químicas e estabelece diretrizes para o gerenciamento ambiental de áreas contaminadas por essas substâncias em decorrência de atividades antrópicas. http://conama.mma.gov.br/?option=com_sisconama\&task=arquivo.download\&id=601

Bronick, C. J. and Lal, R. (2005). Soil structureand management:A review. Geoderma,124,3-22. https://doi.org/10.1016/j.geoderma.2004.03.005 Cabral, O. M. R., Freitas, H. C., Cuadra, S. V., Andrade, C. A., Ramos, N. P., Grutzmacher, P., Galdos, M., Packer, A. P. C., Rocha, H. R. and Rossi, P. (2020). The sustainability of a sugarcane plantation in Brazil assessed by the eddy covariance fluxes of greenhouse gases. Agricultural and Forest Meteorology, 282-283, 107864. https://doi.org/10.1016/j.agrformet.2019.107864 
Cai, L., Xu, Z., Bao, P., He, M., Dou, L., Chen, L., Zhou, Y. and Zhu, Y.-G. (2015). Multivariate and geostatistical analyses of the spatial distribution and source of arsenic and heavy metals in the agricultural soils in Shunde, Southeast China. Journal of Geochemical Exploration, 148, 189-195. https://doi.org/10.1016/j.gexplo.2014.09.010

Camargo, O. A., Moniz, A. C., Jorge, J. A. and Valadares, J. M. A. S. (2009). Métodos de análise química, mineralógica e física de solos do Instituto Agronômico de Campinas [Boletim técnico 106]. Campinas: Instituto Agronômico.

Camilotti, F., Andrioli, I., Marques, M. O., Silva, A. R. and Tasso Junior, L. C. (2009). Avaliação dos teores de metais pesados no solo e na planta de cana-de-açúcar sob adubação com lodo de esgoto e vinhaça. Bioscience Journal, 25, 23-31.

Campos, M. L., Pierangeli, M. A. P., Guilherme, L. R. G., Marques, J. J. and Curi, N. (2003). Baseline concentration of heavy metals in Brazilian Latosols. Communications in Soil Science and Plant Analysis, 34, 547-557. https://doi.org/10.1081/CSS-120017838

Chen, T., Liu, X., Zhu, M., Zhao, K., Wu, J., Xu, J. and Huang, P. (2008). Identification of trace element sources and associated risk assessment in vegetable soils of the urban-rural transitional area of Hangzhou, China. Environmental Pollution, 151, 67-78. https://doi. org/10.1016/j.envpol.2007.03.004

[CONAB] Companhia Nacional de Abastecimento. (2019). Acompanhamento da safra brasileira cana - Safra 2019/20, v.6, n.3. 1ed. [Accessed Mar. 05, 2020]. Available at: https://www.conab.gov.br/info-agro/safras/cana/boletim-da-safra-de-cana-de-acucar

Conceição, F. T., Bonotto, D. M., Jiménez-Rueda, J. R. and Roveda, J. A. F. (2009). Distribution of ${ }^{226} \mathrm{Ra}$, ${ }^{232} \mathrm{Th}$ and ${ }^{40} \mathrm{~K}$ in soils and sugar cane crops at Corumbataí river basin, São Paulo State, Brazil. Applied Radiation and Isotopes, 67, 1114-1120. https://doi.org/10.1016/j. apradiso.2009.02.086

Corbi, J. J., Costa, C. G., Gorni, G. R., Colombo, V. and Rios, L. (2018). Environmental diagnosis of metals in streams near sugarcane cultivation areas: Current and historical analysis in the central region of the state of São Paulo. Anais da Academia Brasileira de Ciências, 90, 2711-2719. https://doi.org/10.1590/0001-3765201820170808

Dieckow, J., Bayer, C., Conceição, P. C., Zanatta, J. A., Martin-Neto, L., Milori, D. B. M., Salton, J. C., Macedo, M. M., Mielniczuk, J. and Hernani, L. C. (2009). Land use, tillage, texture and organic matter stock and composition in tropical and subtropical Brazilian soils. European Journal of Soil Science, 60, 240-249. https://doi.org/10.1111/j.1365-2389.2008.01101.x

Gabe, U. and Rodella, A. A. (1999). Trace elements in Brazilian agricultural limestones and mineral fertilizers. Communications in Soil Science and Plant Analysis, 30, 605-620. https://doi.org/10.1080/00103629909370231

Gharaibeh, M. A., Marschner, B., Heinze, S. and Moos, N. (2020). Spatial distribution of metals in soils under agriculture in the Jordan Valley. Geoderma Regional, 20, e00245. https://doi.org/10.1016/j.geodrs.2019.e00245

Gimeno-García, E., Andreu, V. and Boluda, R. (1996) Heavy metals incidence in the application of inorganic fertilizers and pesticides to rice farming soils. Environmental Pollution, 92, 19-25, 1996. https://doi.org/10.1016/0269-7491(95)00090-9

Graham, M. H. and Haynes, R. J. (2006). Organic matter status and the size, activity and metabolic diversity of the soil microbial community in the row and inter-row of sugarcane under burning and trash retention. Soil Biology and Biochemistry, 38, 21-31. https:// doi.org/10.1016/j.soilbio.2005.04.011

Hage, D. S. and Carr, J. D. (2012). Química analítica e análise quantitativa. São Paulo: Pearson Prentice Hall.

Hejcman, M., Szaková, J., Schellberg, J., Šrek, P. and Tlustoš, P. (2009). The Rengen Grassland Experiment: Soil contamination by trace elements after 65 years of Ca, N, P and K fertilizer application. Nutrient Cycling in Agroecosystems, 83, 39-50. https://doi.org/10.1007/ s10705-008-9197-8

Huang, S., Huang, X. and Fang, B. (2020). Elevated CO2 affects the soil organic carbon fractions and their relation to soil microbial properties in the rhizosphere of Robinia pseudoacacia L: Seedlings in Cd-Contaminated Soils. Journal of Soil Science and Plant Nutrition, 20, 1203-1214. https://doi.org/10.1007/s42729-020-00205-1 
lamaguti, J. L., Moitinho, M. R., Teixeira, D. D. B., Bicalho, E. S., Panosso, A. R. and La Scala Junior, N. (2015). Preparo do solo e emissão de $\mathrm{CO}_{2}$, temperatura e umidade do solo em área canavieira. Revista Brasileira de Engenharia Agrícola e Ambiental, 19, 497-504. https:// doi.org/10.1590/1807-1929/agriambi.v19n5p497-504

Ikematsu, P., Silva, A. M., Paula, F. P., Pajaro, D. N., Silveira, F. M., Alves, S. H. and Bomback, M. (2007). Dimensionamento e estudo dos fatores condicionantes de duas voçorocas localizadas no munícipio de Sorocaba (SP). Caminhos de Geografia, 8, 76-85.

Jeng, A. S. and Singh, B. R. (1995). Cadmium status of soils and plants from a long-term fertility experiment in southeast Norway. Plant Soil, 175, 67-74. https://doi.org/10.1007/BF02413011

Jiao, W., Chen, W., Chang, A. C. and Page, A. L. (2012). Environmental risks of trace elements associated with long-term phosphate fertilizers applications: A review. Environmental Pollution, 168, 44-53. https://doi.org/10.1016/j.envpol.2012.03.052

Juliatti, M. A., Prado, R. M., Barriquelo, M. F. and Lenzi, E. (2002). Cádmio em latossolo vermelho cultivado com milho em colunas: Mobilidade e biodisponibilidade. Revista Brasileira de Ciências do Solo, 26, 1075-1081. https://doi.org/10.1590/S0100-06832002000400025

Kabata-Pendias (2000). Trace elements in soils and plants. Boca Raton: CRC Press. https://doi.org/10.1201/9781420039900

Keshavarzi, A. and Kumar, V. (2020). Spatial distribution and potential ecological risk assessment of heavy metals in agricultural soils of Northeastern Iran. Geology, Ecology, and Landscapes, 4, 87-103. https://doi.org/10.1080/24749508.2019.1587588

Lake, D. L. (1987). Heavy metals in wastewater and sludge treatment process. In J. N. Lester (Ed.), Sludge disposal to land. Boca Raton: CRC Press.

Lal, R. (2004). Soil carbon sequestration impacts on global climate change and food security. Science, 304, 1623-1627. https://doi. org/10.1126/science.1097396

Lorençatto, R. (2019). Determinação de multielementares em fertilizantes usando o MP-AES Agilent 4210 [Nota de Aplicação $5994-$ 0939PTBR]. Saint Claire: Agilent Technologies, Inc.

Malavolta, E. (2006). Manual de nutrição mineral de plantas. Ouro Fino: Ceres.

Marques, M. O., Nogueira, T. A. R., Fonseca, I. M. and Marques, T. A. (2007). Teores de Cr, Ni, Pb e Zn em argissolo vermelho tratado com lodo de esgoto. Revista de Biologia e Ciências da Terra, 7, 133-143.

Martha Junior, G. B., Alves, E. and Contini, E. (2012). Land-saving approaches and beef production growth in Brazil. Agricultural Systems, 110, 173-177. https://doi.org/10.1016/j.agsy.2012.03.001

McBride, M. B. and Spiers, G. (2001). Trace element content of selected fertilizers and dairy manures as determined by ICP-MS. Communications in Soil Science and Plant Analysis, 32, 139-156. https://doi.org/10.1081/CSS-100102999

Mclean, J. E. and Bledsoe, B. E. (1992). Ground water issue: Behavior of metals in soils [EPA/540/S-92/018]. Washington: USEPA.

Minari, G. D., Rosalen, D. L., Cruz, M. C. P., Melo, W. J., Alves, L. M. C. and Saran, L. M. (2017). Agricultural management of an Oxisol affects accumulation of heavy metals. Chemosphere, 185, 344-350. https://doi.org/10.1016/j.chemosphere.2017.07.008

Miśkowiec, P. and Olech, Z. (2020). Searching for the correlation between the activity of urease and the content of nickel in the soil samples: The role of metal speciation. Journal of Soil Science and Plant Nutrition, 20, 1904-1911. https://doi.org/10.1007/s42729-020-00261-7

Munsell Color (Firm). (2010). Munsell soil color charts: with genuine Munsell color chips. Grand Rapids: Munsell Color.

Nelson, D. W. and Sommers, L. E. (1996). Total carbon, organic carbon, and organic matter. In D. L. Sparks, A. L. Page, P. A. Helmke, R. H. Loeppert, P. N. Soltanpour, M. A. Tabatabai, C. T. Johnston, and M. E. Sumner (Eds.), Methods of Soil Analysis: Part 3 Chemical Methods (p. 961-1010). Madison: American Society of Agronomy. https://doi.org/10.2136/sssabookser5.3.c34 
Nogueira, T. A. R., Franco, A., He, Z., Braga, V. S., Firme, L. P. and Abreu-Junior, C. H. (2013). Short-term usage of sewage sludge as organic fertilizer to sugarcane in a tropical soil bears little threat of heavy metal contamination. Journal of Environmental Management, 114, 168-177. https://doi.org/10.1016/j.jenvman.2012.09.012

Nziguheba, G. and Smolders, E. (2008). Inputs of trace elements in agricultural soils via phosphate fertilizers in European countries. Science of the Total Environment, 390, 53-57. https://doi.org/10.1016/j.scitotenv.2007.09.031

Oliveira, A. C. S., Silva, M. A. S., Kliemann, H. J., Soares, R. A. B. and Borges, J. D. (2005). Acúmulo de micronutrientes e de metais tóxicos em latossolo cultivado com cana-de-açúcar fertirrigada com vinhaça. In Congresso de Pesquisa, Ensino e Extensão da UFG - CONPEEX. Proceedings of XIII Seminário de Iniciação Cientifica, 5-7 October. Goiânia, Goiás, Brazil.

Omwoma, S., Lalah, J. O., Ongeri, D. M. K. and Wanyonyi, M. B. (2010). Impact of fertilizers on heavy metal loads in surface soils in Nzoia Nucleus estate sugarcane farms in western Kenya. Bulletin of Environmental Contamination and Toxicology, 85, 602-608. https://doi. org/10.1007/s00128-010-0133-7

Paustian, K., Six, J., Elliott, E. T. and Hunt, H. W. (2000). Management options for reducing $\mathrm{CO}_{2}$ emissions from agricultural soils. Biogeochemistry, 48, 147-163. https://doi.org/10.1023/A:1006271331703

Peris, M., Recatalá, L., Micó, C., Sanchez, R. and Sanchéz, J. (2008). Increasing the knowledge of heavy metal contents and sources in agricultural soils of the European Mediterranean region. Water, Air, and Soil Pollution, 192, 25-37. https://doi.org/10.1007/s11270-008-9631-1

Ramalho, J. F. G. P. and Sobrinho, N. M. B. A. (2001). Metais pesados em solos cultivados com cana-de-açúcar pelo uso de resíduos agroindustriais. Floresta e Ambiente, 8, 120-129.

Reicosky, D. C., Dugas, W. A. and Torbert, H. A. (1997). Tillage-induced soil carbon dioxide loss from different cropping systems. Soil and Tillage Research, 41, 105-118. https://doi.org/10.1016/S0167-1987(96)01080-X

Reynolds, W. D., Drury, C. F., Yang, X. M., Fox, C. A., Tan, C. S. and Zhang, T. Q. (2007). Land management effects on the near-surface physical quality of a clay loam soil. Soil and Tillage Research, 96, 316-330. https://doi.org/10.1016/j.still.2007.07.003

Richards, I. R., Clayton, C. J. and Reeve, A. J. K. (1998). Effects of long-term fertilizer phosphorus application on soil and crop phosphorus and cadmium contents. Journal of Agricultural Science, 131, 187-195. https://doi.org/10.1017/S0021859698005723

Santos, H. G., Jacomine, P. K. T., Anjos, L. H. C., Oliveira, V. A., Lumbreras, J. F., Coelho, M. R., Almeida, J. A., Araújo Filho, J. C., Oliveira, J. B. and Cunha, T. J. F. (2018). Sistema brasileiro de classificação de solos. Brasília: Embrapa.

Silva, F. B. V., Nascimento, C. W. A., Araújo, P. R. M., Silva, L. H. V. and Silva, R. F. (2016). Assessing heavy metal sources in sugarcane Brazilian soils: An approach using multivariate analysis. Environmental Monitoring and Assessment, 188, 457. https://doi.org/10.1007/ s10661-016-5409-x

Silva, F. C. (2009). Manual de análises químicas de solos, plantas e fertilizantes. Brasília: Embrapa Informação Tecnológica.

Spera, S., VanWey, L. and Mustard, J. (2017). The drivers of sugarcane expansion in Goiás, Brazil. Land Use Policy, 66, 111-119. https:// doi.org/10.1016/j.landusepol.2017.03.037

Teixeira, J. M., Moura, J. M., Silva, U. C., Calazans, G. M., Oliveira, A. C. and Marriel, I. E. (2010). Estoque de nitrogênio total e relação C/N influenciados pelo sistema de manejo e uso do solo de Cerrado [Paper presentation]. In XXVIII Congresso Nacional de Milho e Sorgo, 29 August-2 September. Goiânia, Goiás, Brazil.

Tiller, K. G. (1989). Heavy metals in soils and their environmental significance. In B. A. Stewart (Ed.), Advances in soil science (p. 113142). New York: Springer. https://doi.org/10.1007/978-1-4612-3532-3_2

Toor, G. S. and Haggard, B. E. (2009). Phosphorus and trace metal dynamics in soils amended with poultry litter and granulates. Soil Use and Management, 25, 409-418. https://doi.org/10.1111/j.1475-2743.2009.00235.x 
[USEPA] United States Environmental Protection Agency. (2003). Guidance for developing ecological soil screening levels OSWER Directive 9285.7-55]. Washington: USEPA. [Accessed Mar. 03, 2020]. Available at: https://nepis.epa.gov/Exe/ZyPDF.cgi/P100CDCG. PDF?Dockey=P100CDCG.PDF

[USEPA] United States Environmental Protection Agency. (2005a). Ecological soil screening levels for lead. Washington: USEPA. [Accessed Mar. 03, 2020]. Available at: https://rais.ornl.gov/documents/eco-ssl_lead.pdf

[USEPA] United States Environmental Protection Agency. (2007b). Method 3051A: Microwave assisted acid digestion of sediments, sludges, soils and oils. Washington: USEPA.

[USEPA] United States Environmental Protection Agency. (2007c). Ecological soil screening levels for copper: Interim final [OSWER Directive 9285.7-68]. Washington: USEPA. [Accessed Mar. 03, 2020]. Available at: https://www.epa.gov/sites/default/files/2015-09/ documents/eco-ssl_copper.pdf

[USEPA] United States Environmental Protection Agency. (2007a). Ecological soil screening levels for zinc: Interim final [OSWER Directive 9285.7-73]. Washington: USEPA. [Accessed Mar. 03, 2020]. Available at: https://nepis.epa.gov/Exe/ZyPDF.cgi/P100CEBT. PDF?Dockey=P100CEBT.PDF

[USEPA] United States Environmental Protection Agency. (2008). Ecological soil screening levels for chromium: Interim Final [OSWER Directive 9285.7-66]. Washington: USEPA. [Accessed Mar. 03, 2020]. Available at: https://nepis.epa.gov/Exe/ZyPDF.cgi/P100CDY4. PDF?Dockey=P100CDY4.PDF

van Raij, B., Cantarella, H., Quaggio, J. A. and Furlani, A. M. C. (1997). Recomendações de adubação e calagem para o estado de São Paulo [Boletim técnico n ${ }^{100}$ ]. Campinas: Instituto Agronômico.

Wei, B. and Yang, L. (2010). A review of heavy metal contaminations in urban soils, urban road dusts and agricultural soils from China. Microchemical Journal, 94, 99-107. https://doi.org/10.1016/j.microc.2009.09.014

Wood, A. W. (1991). Management of crop residues following green harvesting of sugarcane in north Queensland. Soil and Tillage Research, 20, 69-85. https://doi.org/10.1016/0167-1987(91)90126-I

Yadav, D. V, Radha, J. and Rai, R.K. (2010). Impact of Heavy Metals on Sugarcane. In I. Sherameti, and A. Varma (Eds.), Soil Heavy Metals (p. 339-367). Belin: Springer. https://doi.org/10.1007/978-3-642-02436-8_16 